JALSAH: The Journal of al-Quran and as-Sunnah Studies

Faculty of Ushuludin IIQ An-Nur Yogyakarta

Vol. 1 No. 12021

https://jurnalannur.ac.id/index.php/jalsah

\title{
Kritik Ibn al-Jauzi Terhadap Hadis dalam Kitab Ihya Ulum ad-Din dan Pembelaan Abu al-Fadl al-Iraqi
}

\author{
A'an Mujibur Rohman \\ UIN Sunan Kalijaga Yogyakarta, Indonesia \\ 筫 aanmujib19@gmail.com \\ DOI: https://doi.org/10.37252/jqs.v1i1.130
}

\begin{abstract}
In the world of Islamic intellectuals, Al-Ghazali is one of the Sufistic figures who understands Islam very well. Arguments and ways of thinking about philosophy, monotheism and others were able to become a bridge for Muslims in that era. But apart from the intellectual prowess of al-Ghazali can not be separated from the criticism of his thinking. Some scholars at that time tried to criticize al-Ghazali's thoughts, especially about the hadith arguments that he used in Islamic law. Some scholars' considered that al-Ghazali used the hadith maudlu'. This is as seen in one of his monumental works, Ihya 'Ulum ad-Din, both for the purpose of at-targhib (providing motivation) and at-tarhib (scaring), and/or fadhail al-a'mal (the virtue of attitude/ behavior). It is interesting to briefly examine the epistemological framework of hadith in al-Ghazali's thought, which according to some scholars' has a tasahhul (loose) attitude in terms of hadith transmission, thus drawing criticism from some scholars and even orientalists, and the basis held by al-Ghazali in narrating and using hadiths that are af and even willing' quality, especially those related to haram and halal. However, this monumental book by alGhazali is considered a very great book in its era until now because it includes various types of knowledge.
\end{abstract}

Keywords: al-Ghazali, critical studies, hadith studies, Ihya ulum ad-din

Abstrak

Al-Ghazali merupakan salah satu tokoh sufistik yang sangat memahami tentang Islam. Argumen dan cara berfikir mengenai filsafat, tauhid dan lainnya mampu menjadi jembatan bagi umat Islam pada era itu. Namun terlepas dari kehebatan intelektual al-Ghazali tidak terlepas dari kritik terhadap pemikiran nya. Beberapa ulama' masa itu mencoba mengkritik atas pemikiran alGhazali, terutama tentang dalil hadis yang beliau gunakan pada hukum islam. Beberapa ulama' menilai bahwa al-Ghazali menggunakan hadis daif dan maudü. Hal ini seperti yang tampak dalam salah satu karya monumentalnya, Ihya 'Ulüm ad-Dìn, baik untuk tujuan at-targīb (pemberian motivasi) maupun at-tarbīb (menakuti-nakuti), dan atau faḍäl al-a'mäl (keutamaan sikap/perilaku). Menjadi menarik untuk mengkaji secara singkat kerangka epistemologi hadis dalam pemikiran alGhazali, yang menurut beberapa kalangan ulama' mempunyai sikap tasabhul (longgar) dalam hal periwayatan hadis sehingga menuai kritik dari sebagaian ulama bahkan orientaslis, dan dasar yang dipegang al-Ghazali dalam meriwayatkan dan mempergunakan hadis-hadis yang berkualitas daif bahkan maud $\bar{u}^{\prime}$ khususnya yag berkaitan dengan haram dan halal. Walaupun demikian, kitab monumental karangan al-Ghazali ini dianggap sebagai kitab yang sangat hebat dalam eranya sampai sekarang karena di dalamnya merangkum berbagai jenis ilmu.

Kata Kunci: al-Ghazali, Ihya 'Ulüm ad-Din, Telaab kritis Pemikiran Hadis 
JALSAH: The Journal of al-Quran and as-Sunnah Studies

Faculty of Ushuludin IIQ An-Nur Yogyakarta

Vol. 1 No. 12021

https://jurnalannur.ac.id/index.php/jalsah

\section{Pengantar}

Berbagai literatur yang memperbincangkan sederetan nama tokoh dan pemikir muslim, nama al-Ghazali tidak pernah lepas dari sorotan, bahkan banyak yang mengundang pro dan kontra di kalangan filosof, para tokoh Islam serta tak ketinggalan dari kalangan para ulama'. Seperti dalam Kitab Ihya' 'Ulum al-Din, salah satu karya manumental al-Ghazali, mengandung banyak hadis yang diragukan kesahihannya. Para ulama' mempunyai pandangan berbeda mengenai Ihya' (Yussof: ttp:5). Cara yang ditempuh al-Ghazali memang beda, karakteristik yang dimunculkan dalam Ibya 'Ulüm adDin dimulai dengan menguraikan tentang "islah al-Qulub", misal ketika membicarakan keutamaan keutamaanya dimulai dengan memuji memakai ayat-ayat lalu hadis, khabar dan atsar (Nisa, 2016:2).

Penelusuran atas kritik kalangan ulama' seperti Abu al-Faraj Abdul ar-rahman Ibnu al-Jauzi menjadi bagian penting dalam upaya menjembatani pandangan yang berbeda (Abdullah, 2003:52). Ketokohan al-Ghazali memang cukup menarik untuk dikaji, di satu sisi sebagaian ilmuwan memujanya dengan menggelarinya hujjahtu al-Islam, namun banyak ilmuwan yang juga mengkritiknya (Jamhari, 2015:2). Lontaran kritik tersebut sering ditemukan dan dijumpai dalam kajian buku maupun dalam artikel tentang kontroversi pemikiran al-Ghazali. Namun masing jarang yang melihat kontorversi pemikiran al-Ghazali khususnya metodologi penggunaan hadis dalam kitab Ibya Ulüm adDin dalam dua sudut pandang, yakni antara kalangan yang kontra dan pro. Padahal dua pihak tersebut bilamana dikaji lebih dalam maka kita bisa melihat lebih makro dan tentu akan menambah khazanah keintelektualan kalangan muslim (Abdullah, 1996:34). Selama ini, tidak bisa dipungkiri bahwa secara umum kajian pada hadis berkutat pada dua persoalan, yaitu kritik sanad (naqd al-sanad/al-naqd al-khârijî/ kritik eksternal) dan kritik matan (naqd al-matn/alnaqd al-dâkbilî/kritik internal). Keduanya adalah cara yang dipergunakan untuk memilih dan memilah mana hadis yang dapat dipertanggungjawabkan otentisitasnya sampai Nabi dan mana yang tidak dapat dipertanggungjawabkan (Suryadi, 2015:2).

Artikel ini menjelaskan tentang kritik kalangan ulama' terhadap pemikiran alGhazali yang menyangkut tentang penggunaan dalil hadis sebagai argumentasi yang berkenaan dengan masalah ketentuan hukum Islam dalam Ibya 'Ulüm ad-Dìn, di mana sebagain ulama' menganggap al-Ghazali di beberapa hadis menggunakan hadis daif bahkan maudü. Bagaimanakah kerangka epistemologi hadis dalam pemikiran al-Ghazali? Mengapa al-Ghazali mempunyai sikap tasahhul (longgar/tidak ketat) dalam hal periwayatan hadis sehingga memunculkan kritik dari kalangan ulama' seperti Abu al-Faraj Abdul al-Rahman Ibnu al-Jauzi? Dasar apa yang dipegang oleh al-Ghazali dalam meriwayatkan dan mempergunakan hadis-hadis yang berkualitas daîf serta maudü' seperti yang terdapat dalam kitab Ibya 'Ulüm ad-Din sehingga sampai mendapat pembelaan dari 
JALSAH: The Journal of al-Quran and as-Sunnah Studies

Faculty of Ushuludin IIQ An-Nur Yogyakarta

Vol. 1 No. 12021

https://jurnalannur.ac.id/index.php/jalsah

Abu al-Faḍl al-Iraqi? Ketiga problem tersebut diatas akan dikaji dalam artikel ini dengan melihat metodologi yang digunakan dan pandangan ulama' yang mengkaji kitab tersebut.

Dinamika pemikiran Al Ghazali sangat unik, keunikan inilah sehingga menimbulkan polemik tentang pemikirannya, baik oleh orang Islam sendiri maupun kaum orientalis. Pemikiran Al Ghazali secara metodologis mengikuti Asy'ariyah. Namun di balik kehebatan intelektualnya, ia sebagai manusia biasa tidak pernah lepas dari kelemahankelemahan yang sangat dipengaruhi oleh lingkungan sekitar. Dalam menyusun Ihya 'Ulüm ad-Din pada dasarnya al-Ghazali memakai sistematika ilmu fiqh dengan pengelompokan arbi'ah, terdiri dari empat rub'. al-Ghazali melakukan rekontruksi atas setiap rub' dengan penataan baru pada materi-materinya. Namun al-Ghazali juga memberikan landasan pokok bagi ibadah-ibadah yang lazimnya dimulai dengan țaharah, kemudian shalat dan seterusnya.

\section{Pembahasan}

\subsection{Kajian Hadis Nabi Dalam Kitab al-Ghazali}

Mayoritas umat islam sepakat bahwa dasar sumber pokok ajaran Islam adalah alQur'an dan hadis (Suryadi, 2015:177). Hadis sebagai ajaran Islam di dalamnya terkandung ucapan, perbuatan dan ketetapan dari Rasulullah saw (Suryadilaga, 2017:215). Mulai dari hadis yang mutawatir, dan hadis masyhur yang bisa diamalkan oleh Nabi, sahabat, tabi'in dan ulama'. Setelah itu disusul oleh beberapa hadis yang dianggap sahih oleh ulama' tertentu, berdasarkan sanad dari ulama' lain yang berpredikat tsiqah (terpercaya) (Abdulla, 2003:1). Kemudian disusul lagi beberapa hadis Nabi yang diperdebatkan oleh ulama' apakah hadis tersebut sahih atau dhaif. Perdebatan itu didasarkan pada kondisi sanad atau pada matan. Model hadis yang tersebut akhir ini menimbulkan banyak perbedaan, maka ulama' menyelesaikan dengan bentuk ijtihad. Nabi Muhammad sendiri menganjurkan kepada kita untuk menjaga sunnahnya dari perubahan (Irham, 2015:96). Sejarah perkembangan studi hadis dari fase ke fase memang menarik untuk diperbincangkan, mengingat peran hadis begitu sentral bagi umat Islam (Maulana, 2016:111). Perkembangan ilmu pengetahuan dan gejala sosial menjadi aspek penting yang tidak dapat dipisahkan dari perjalanan hadis Nabi (Muhtador, 2019:185). Hadis yang sebelumya merupakan perkataan, perbuatan dan taqrir Nabi SAW yang disampaikan Nabi saw kepada sahabatnya melalui majlis yang dibuat Rasulullah saw. atau melalui media lainnya, kini menjadi suatu yang terbukukan dan beragam kitab yang di dalamnya memiliki metode masing-masing (Suryadilaga, 2014:199).

Ada tiga penilaian hadis daiff, yaitu pertama, ulama' berpendapat bahwa hadis daif tidak dapat diamalkan, baik untuk hukum atau untuk keutamaan amal ibadah (Salihima, 2010:6). Kedua, ulama' berpendapat bahwa hadis dapat diamalkan baik untuk hukum syara' fa däilul a'mäl. Menurut al-Sayuthi, ucapan ini mungkin dari Abu Dawud dan Ahmad Bin Hambal, keduanya berpendirian bahwa mengamalkan hadis daif lebih kuat dari pada 
JALSAH: The Journal of al-Quran and as-Sunnah Studies

Faculty of Ushuludin IIQ An-Nur Yogyakarta

Vol. 1 No. 12021

https://jurnalannur.ac.id/index.php/jalsah

mengamalkan pendapat seorang tokoh. Ketiga, ulama berpendapat bahwa hadis ḍif asal bukan maudü' dapat digunakan untuk faḍäilul a'māl dengan persyaratan tertentu, tetapi tidak boleh untuk menentukan hukum syariat, demikian pendapat imam Nawawi.

Hadis Nabi baik sahih, hasan, ḍaif atau maudü' telah banyak dikutip oleh kalangan muslim untuk kitab karangan dan sebagainya. Namun pemikiran baru yang muncul baik dalam hal agama maupun kemasyarakatan tidak semuanya didukung oleh hadis sahih. Oleh karena itu, sebagaian ulama' ada yang membuat kerangka berfikir sendiri, agar hadis Nabi yang dituangkannya dapat diterima oleh ahli hadis dan bisa sejalan dengan alur pemikiran. Hal ini sepertinya tampak dalam pengalaman al-Ghazali ketika menulis kitab Ibya 'Ulüm ad-Dìn, di mana di dalamnya terdapat banyak menjelaskan salah satunya tentang keutamaan ilmu yang menjadi rujukan ilmiah bagi seorang muslim (Suryadilaga, 2013:22).

\subsection{Latar Belakang Penyusunan Kitab Ihya 'Ulūm ad-Dīn}

Salah satu faktor yang melatar belakangi penyusunan kitab Ihya 'Ulüm ad-Din yaitu untuk menghidupkan ilmu agama semenjak ilmu-ilmu agama menjadi bahan perdebatan yang kosong pada ulama' kalam Mas'udi, 2013:20). Hal itu dimaksudkan dimaksudkan agar ilmu-ilmu agama dapat kembali menempati posisinya yang benar dan supaya dapat dihayati secara utuh untuk diamalkan secara cermat dan bersemangat. Pada hakekatnya kitab Ibya 'Ulüm ad-Din adalah hasil pengalaman, pengembaraan, penjelajahan, dan pendalaman al-Ghazali di dalam berbagai ilmu. Kitab itu adalah hasil karya positif setelah ia mengalami keraguan (syak) (Asari, 2019:9). Keraguan terhadap segala persoalan kepercayaan dan pada akhirnya keraguan itu sendiri sedikit demi sedikit hilang, berganti dengan keyakinan. Hal itulah yang kemudian disajikan oleh al-Ghazali kepada kaum muslimin dengan kitabnya yang terkenal di segala penjuru dunia. Namun demikian, sesungguhnya tidak ada yang benar-benar sempurna di atas bumi ini. Maka karya alGhazali yang berupa kitab Ihya Ulüm ad-Din pun tak lepas dari kekurangan, misalnya dalam penggunaan hadis, yang ternyata banyak dinilai oleh para pakar hadis sebagai hadis yang berkualitas, ḍaif bahkan maud $\ddot{u}$.

Salah satu pertimbangan al-Ghazali menulis Ibya 'Ulüm ad-Din adalah karena melihat praktek pelaksanaan ibadah umat sangat formalistik, semata-mata menggunakan pendekatan hukum. Sehingga ibadah mahdah lebih ditekankan pada aspek formalitasnya. Dalam hal ini tentunya tidak bisa dilepaskan dari pengaruh pemahaman fiqih yang formalistik itu. Adapun hadis-hadis yang dikutip al-Ghazali, khususnya dalam Ibya Ulüm ad-Din, mungkin karena desakan waktu, sehingga di samping ada hadis-hadis yang sahih juga banyak hadis-hadis yang daif. Hal ini juga disimpulkan oleh Zain al-Din Abd alRahman al-'Iraqi setelah dia meneliti hadis-hadis tersebut dan menulisnya dalam buku Ikbbär al-Ihya Ulum ad-Din bi Akbbar al-Ihya Ulum ad-Din. Buku ini berisi tentang takbrij al-hadis sekaligus tahqiq al-Hadis yang termuat dalam Ibya Ulüm ad-Din. Mungkin bisa dimaklumi mengapa al-Ghazali bersikap demikian, karena ia memang bukan ahli hadis, ia lebih dikenal ulama tasawuf (Sidik, 2020:9) dan filosof (Amien, 2007:14). 
JALSAH: The Journal of al-Quran and as-Sunnah Studies

Faculty of Ushuludin IIQ An-Nur Yogyakarta

Vol. 1 No. 12021

https://jurnalannur.ac.id/index.php/jalsah

Dalam kitab Ibya 'Ulüm ad-Din setiap rub' terdiri dari 10 bab atau sub-bagian. Setiap kitab terdiri dari beberapa bab dan setiap bab diuraikan dalam beberapa judul permasalahan. Kerangka bahasan atau isi dari kitab Ibya Ulüm ad-Din selengkapnya adalah sebagai berikut:

a. Rub' Pertama (Ibadat)

Kitab pertama, tentang ilmu;

Kitab kedua, tentang landasan-landasan akidah (kepercayaan);

Kitab ketiga, tentang rahasia kebersihan;

Kitab keempat, tentang rahasia shala

Kitab kelima, tentang rahasia zakat;

Kitab keenam, tentang rahasia puasa;

Kitab ketujuh, tentang rahasia haji;

Kitab kedelapan, tentang tata cara tilawah al-Qur'an;

Kitab kesembilan, tentang dzikir dan do'a

Kitab kesepuluh, tentang tertib wiridan.

b. Rub'Kedua ('adat)

Kitab pertama, tentang tatacara makam

Kitab kedua, tentang tatacara nikah

Kitab ketiga, tentang hukum berusaha (bekerja untuk mata pencaharian)

Kitab keempat, tentang yang halal dan yang haram

Kitab kelima, tentang pergaulan dengan berbagai macam lapisan masyarakat;

Kitab keenam, tentang hidup menyendiri

Kitab ketujuh, tentang tatacara bepergian

Kitab kedelapan, tentang seni suara dan tari

Kitab kesembilan, tentang amar ma'ruf dan nahi munkar

Kitab kesepuluh, tentang tatacara kehidupan dan akhlak Nabi

C. Rub' Ketiga (Muhlikat)

Kitab pertama, tentang analisis keajaiban hati;

Kitab kedua, tentang olah batin (latihan menjalani kehidupan ruhaniah);

Kitab ketiga, tentang hama syahwat;

Kitab keempat, tentang hama bicara;

Kitab kelima, tentang hama marah, benci dan dengki;

Kitab keenam, tentang celaan hidup mewah;

Kitab ketujuh, tentang celaan menumpuk harta dan berlaku pelit

Kitab kedelapan, tentang celaan unjuk kuasa dan pamer diri

Kitab kesembilan, tentang celaan berlaku takabur dan bangga diri

Kitab kesepuluh, tentang celaan manipulasi moral.

D. Rub'Keempat (Munjiat)

Kitab pertama, tentang Shalat

Kitab kedua, tentang sabar dan syukur

Kitab ketiga, tentang cemas dan harap 
JALSAH: The Journal of al-Quran and as-Sunnah Studies

Faculty of Ushuludin IIQ An-Nur Yogyakarta

Vol. 1 No. 12021

https://jurnalannur.ac.id/index.php/jalsah

Kitab keempat, tentang hidup-sederhana

Kitab kelima; tentang tauhid dan tawakal

Kitab keenam, tentang cinta,.rindu, tenteram dan pasrah

Kitab ketujuh, tentang niat, kesungguhan hati dan ihlas

Kitab kedelapan, tentang mawas diri

Kitab kesembilan, tentang kegiatan berpikir, dan

Kitab kesepuluh, tentang perhatian terhadap maut

Menyimak rincian bahasan kitab Ihya 'Ulum ad-Din seperti yang digambarkan di atas, tampak betapa luasnya kajian dalam kitab tersebut. Aspek kehidupan manusia yang berkaitan dengan unsur material maupun unsur mental spiritual dijelaskan di dalamnya. al-Ghazali memulai pembahasan kitabnya dengan masalah ilmu sebagai ciri utama dari manusia.

\subsection{Telaah Kritis Pemikiran Hadis Al-Ghazali}

Terdapat tiga argumentasi yang dikemukakan oleh al-Ghazali berkenaan dengan masalah kedudukan hadis sebagai sumber kedua agama Islam setelah al-Qur'an. Pertama, terdapat bukti adanya mukjizat Rasulullah saw yang dapat dijadikan kebenaran ucapannya; Kedua, adanya perintah Allah swt dalam al-Qur'an yang menyatakan bahwa umat Islam harus mengikuti Rasulullah saw, dan Ketiga terdapat petunjuk dalam al-Qur'an yang menegaskan bahwa Rasulullah saw tidak pernah berkata selain apa yang diwahyukan Allah kepadanya. Lebih lanjut al-Ghazali mengatakan bahwa sebagaian wahyu itu ada yang dibacakan langsung kepada Nabi saw (yutla) yang kemudian disebut al-Kitab, dan ada yang tidak dibacakan langsung kepada Nabi saw (la yutla) yang kemudian dikenal dengan as-Sunnah. Dengan demikian, menurut al-Ghazali, as-Sunnah atau hadis itu menjdi sumber agama Islam kedua setelah Al-Qur'an. Hanya saja tidak semua hadis yang dinisbatkan kepada Rasulullah dengan serta merta dapat diterima sebagai ajaran Islam, melainkan harus diuji terlebih dahulu validitasnya melalui kaidah ilmu hadis.

Dalam teori al-Ghazali, suatu kebenaran yang diperoleh melalui tawatur harus berdasarkan dua premis, yaitu: Pertama, apabila orang-orang yang mendengar kebenaran khabar tersebut tidak sepakat untuk berdusta, melainkan membenarkan khabar yang dimaksud walaupun mereka berbeda keadaan dan tujuannya. Kedua, mereka sepakat menerima khabar tersebut sebagai suatu peristiwa yang pernah ada. Dengan demikian, kebenaran kbabar tersebut diperoleh melalui hubungan antara daya pikir dengan dua premis di atas, sehingga kebenarannya tidak dapat dikategorikan ke dalam kebenaran yang bernilai universal. Lebih lanjut al-Ghazali mengemukakan empat syarat diterimanya suatu khabar sebagai khabar mutawatir.

- Rangkaian periwayatnya didasarkan atas suatu ilmu (pengetahuan) bukan Zanni.

- Pengetahuan para periwayatnya tentang khabar harus merupakan pengetahuan yang pasti berdasarkan pengetahuan empirik (inderawi).

- Sifat dan jumlah perawinya harus sama pada setiap tingkatannya. 
JALSAH: The Journal of al-Quran and as-Sunnah Studies

Faculty of Ushuludin IIQ An-Nur Yogyakarta

Vol. 1 No. 12021

https://jurnalannur.ac.id/index.php/jalsah

- Kategori jumlah bilangan orang yang menyampaikan khabar tersebut harus termasuk dalam kategori bilangan sempurna.

Adapun yang dimaksud dengan pengertian hadis ahad, menurut teori al-Ghazali , adalah "Hadis (baca: khabar) yang tidak mencapai batas mutawatir yang dapat memberikan suatu ilmu (pengertian atau pengetabuan)".

Dengan demikian, hadis yang dinukilkan oleh lima atau enam perawi, umpamanya, maka hadis tersebut masih dikatakan sebagai hadis ahad, kecuali perkataan Rasulullah yang telah diketahui kesahihannya, maka tidaklah dikatakan sebagai hadis ahad. Menurut al-Ghazali, hadis ahad,tidak dapat dipergunakan untuk mencapai suatu ilmu (sama sekali tidak berguna untuk ilmu). Adapun apa yang dinukilkan oleh para ahli hadis bahwa hadis ahad dapat berguna untuk suatu ilmu pengetahuan, dalam hal ini adalah ilmu pengetahuan yang diamalkan, karena prasangka (Zanni) juga bisa dinamakan ilmu pengetahuan. Oleh sebab itu, sebagian orang mengatakan bahwa hadis ahad berguna untuk ilmu lahiriah karena ia bersifat Zanni. Pada dasarnya. pembagian hadis menurut teori al-Ghazali sama dengan pembagian hadis yang dilakukan oleh para ulama hadis pada umumnya, yakni terbagi menjadi mutawatir dan ahad. Akan tetapi, al-Ghazali tidak menyebutkan secara jelas tentang pembagian hadis berdasarkan maqbul dan mardud-nya suatu hadis (sahih, hasan dan da'if). Klasifikasi hadits yang disusun oleh al-Ghazali dapat dipetakan menjadi 3 (tiga) narasi besar, yakni

1. Hadis yang harus diterima kebenarannya (ma yajibu tas'diquhu), bentuk hadis yang taken for granted seperti ini adalah:

- Khabar yang disampaikan oleh sejumlah orang secara tawatur kendatipun tidak terdapat dalil lain yang menunjukkan kebenarannya. Jika khabar itu tidak mutawatir, maka kebenarannya harus diketahui melalui dalil lain yang mendukung kebenarannya.

- Khabar yang datang dari Allah yang dikonfirmasikan baik oleh Rasulullah maupun dari Allah sendiri (hadis qudsi).

- Khabar dari Rasulullah yang telah dibuktikan kebenarannya melalui mu'jizat Rasulullah.

- Khabar yang disampaikan umat yang terpelihara dari kemungkinan berdusta, dalam arti setiap orang yang menerima khabar itu menyatakan kebenarannya.

- Khabar yang sesuai dengan firman Allah, Rasulullah, umat atau orang yang membenarkannya, atau melalui dalil naqli dan aqli.

- Setiap khabar sahih yang disampaikan oleh orang-orang yang semasa dengan Rasulullah, sementara Rasulullah sendiri mendengarnya dan tidak melalaikan khabar tersebut tetapi mendiamkannya.

2. Setiap khabar yang diriwayatkan oleh sekelompok jama'ah dan sementara jama'ah itu membiarkannya. Sementara ada suatu kebiasaan di kalangan jama'ah tersebut bahwa apabila terjadi pendustaan periwayatan, mereka tidak boleh tinggal diam. 
JALSAH: The Journal of al-Quran and as-Sunnah Studies

Faculty of Ushuludin IIQ An-Nur Yogyakarta

Vol. 1 No. 12021

https://jurnalannur.ac.id/index.php/jalsah

3. Hadis yang wajib ditolak atau didustakan kebenarannya (ma yajibu takzibuhu), bentuk hadis ini meliputi:

- Khabar yang bertentangan dengan akal dan pikiran yang sehat, panca indera, kenyataan serta khabar mutawatir.

- Khabar yang bertentangan dengan nash yang qat'i (al-Kitab, al-Hadis alMutawatir, dan ijma').

- Khabar yang jelas-jelas ditolak (didustakan) oleh orang banyak, yang menurut kebiasaan mustahil mereka berdusta.

- Khabar yang tidak dinukilkan dan diriwayatkan oleh orang banyak.

4. Hadis yang harus diperlakukan netral (ma yajibu tawaqqufuhu), yaitu hadis yang berkaitan dengan persoalan hukum-hukum syara' dan ibadah yang belum diketahui benar-tidaknya hingga adanya dalil yang membenarkan atau menolaknya.

\subsection{Pandangan Ibnu Jauzi Terhadap Hadis di Kitab Ihya Ulūm ad-Dīn}

Meskipun posisi Ihya Ulüm ad-Din di tengah-tengah keilmuan Islam sangat tinggi, bukan berarti kitab ini terlepas sepenuhnya dari koreksi dan kritik. Banyak sekali komentar negatif dan bantahan yang ditujukan kepada Al-Ghazali atas karya monumentalnya ini, utamanya dalam studi hadis yang beliau sajikan. hadis-hadis Ibya 'Ulum ad-Din ditengarai banyak bermasalah oleh beberapa kritikus hadis. Keberadaannya menjadi sorotan utama dan sebagai bahan pokok kritikan para rival Al-Ghazali, semisal al-Hafizh Abu al-Faraj Abd al-Rahman Ibnu al-Jauzi.

Ibnu Jauzi yang dikenal anti Ihya 'Ulüm ad-Din banyak memfonis palsu pada hadishadis yang ditulis al-Ghazali dalam kitab tersebut. Dinamika inilah yang selanjutnya diangkat kepermukaan oleh kelompok ekstrimis dan orentalis untuk menolak sepenuhnya isi kitab Ibya Ulüm ad-Din. lebih-lebih, kelompok ini tanpa malu-malu menyebut alGhazali sebagai pemalsu hadis. Pemalsuan tersebut, dalam pandangan mereka, merupakan hal wajar karena al-Ghazali tidak membidangi studi hadis dalam kajian keislamanya.

Imam Ibnu dalam kitab Minhäjul Qosidin berkata: "Ketahuilah, bahwa kitab Ibya Uhum ad-Din di dalamnya terdapat banyak kerusakan (penyimpangan) yang tidak diketahui kecuali oleh para ulama. Penyimpangannya yang paling ringan (dibandingkan penyimpangan-penyimpangan besar lainnya) adalah hadis-hadis palsu dan batil (yang termaktub di dalamnya), juga hadis-hadis manqüf (ucapan shahabat atau tabi'in) yang dijadikan sebagai hadis marfü' (ucapan Rasulullah shallallahu 'alaihi wa sallam). Semua itu dinukil oleh penulisnya dari referensinya, meskipun bukan dia yang memalsukannya”.

\subsection{Posisi Pemikiran Hadis al-Ghazali dan Pembelaan Ibnu 'Iraqi}

Juhaya S. Praja dalam Ilyas dan Mas'udi (1996:220) menjelaskan bahwa terdapat tiga argumentasi yang dikemukakan oleh al-Ghazali berkenaan dengan masalah 
JALSAH: The Journal of al-Quran and as-Sunnah Studies

Faculty of Ushuludin IIQ An-Nur Yogyakarta

Vol. 1 No. 12021

https://jurnalannur.ac.id/index.php/jalsah

kedudukan hadis sebagai sumber kedua agama Islam setelah Al-Qur'an. Ketiga argumentasi tersebut adalah: Pertama, terdapat bukti adanya mukjizat Rasulullah saw yang dapat dijadikan kebenaran ucapannya; Kedua, adanya perintah Allah swt dalam al-Qur'an yang menyatakan bahwa umat Islam harus mengikuti Rasulullah saw, dan Ketiga, terdapat petunjuk Al-Qur'an yang menegaskan bahwa Rasulullah saw tidak pernah berkata selain apa yang diwahyukan Allah kepadanya (QS.53:3-4).

Kita sering mendengar selentingan orang-orang tertentu bahwa hadis-hadis dalam kitab Ihya 'Ulüm ad-Din banyak yang daif bahkan maudü'. Selentingan itu tetap terdengar meski Imam al-Ghazali sendiri pernah menyebutkan bahwa hadis yang ia tulis selalu ditanyakan secara langsung kepada Rasulullah saw., baik melalui mimpi maupun terjaga (bertemu dalam keadaan sadar). Pernyataan al-Ghazali tersebut tidak bisa dijadikan parameter dalam memastikan kesahihan sebuah hadis. Karena secara prosedur, penelitian otentisitas hadis tidak bisa dilakukan melalui mimpi atau bertemu langsung dengan orang yang sudah wafat. Ini tidak bisa diteliti kembali. Melihat kesimpangsiuran hadis dalam kitab Ihya 'Ulüm ad-Din tersebut, muncullah seorang ulama kelahiran Mahran yang menulis sebuah kitab berjudul al-Mughni' 'an Hamli Asfa'r fi al-Asfar yang merupakan kitab takhrij atas hadis-hadis yang ada dalam Ihya 'Ulüm ad-Din.

al'Iraqi sebenarnya menulis dua buah kitab untuk takhrij hadis-hadis di dalam Ibya Uhim ad-Din, yaitu: (1) Kitab besar yg beliau karang pada 751H. Tapi beliau tidak menyiapkannya. (2) Kitab yg lebih kecil yang beliau terbitkan pada $760 \mathrm{H}$ yang berjudul alMughni' 'an Hamli Asfa'r fi al-Asfar yg akhirnya tersebar ke seluruh dunia bersama-sama kitab Ibya 'Ulüm ad-Din. Apa yg mendorong al-'Iraqi bersungguh berkhidmat kepada kitab Ihya 'Ulum ad-Din? ini semata mata karena beliau melihat kehebatan kitab Ihya Ulüm adDin. Maka, beliau akan berbangga di hadapan Allah karena membersihkan kitab Ihya 'Ulüm ad-Din yang menjadi pedoman ulama lintas zaman. Lalu murid beliau, Imam Ibnu Hajar al-Asqolani (wafat $852 \mathrm{H}$ ) yg telah ber-talaqqi dengannya selama 10 tahun telah menyempurnakan apa yg terluput daripada karangan gurunya dalam satu jilid kitab. Imam Zainuddin al-Qosim bin Qutlubugho al-Hanafi (wafat 879H) pula telah mengarang kitab Tuhfatu al-Abyà fì mā Fatā min Takharïji Abädis al-Ihyā untuk menyempurnakan lagi takhrij terhadap hadis-hadis di dalam kitab Ibya 'Ulüm ad-Din. Para ulama seolah-olah bergairah untuk melibatkan diri mereka dalam 'penyenpurnaan' kitab Ibya 'Ulüm ad-Din yang berharga ini.

Perlu dipahami bahwa hadis-hadis lemah atau beberapa hadis palsu, bukanlah referensi utama al-Ghazali melainkan sekedar tambahan dari dalil shahîh yang mendasari ijtihadnya. al-Ghazali selalu mendahulukan landasan ijtihadnya dengan dasar yang shahîh sebelum kemudian menampilkan dalil lain yang selevel atau di bawahnya dan sekali lagi, bilangan tersebut sangatlah kecil. tentu sangat na'if bila bagian kecil dari kekeliruan (untuk tidak mengatakan kesalahan karena keduanya memiliki perbedaan makna yang signifikan) tersebut dapat menghapus pada seluruh kebenaran yang terkandung dalam kitab Ihya. 
JALSAH: The Journal of al-Quran and as-Sunnah Studies

Faculty of Ushuludin IIQ An-Nur Yogyakarta

Vol. 1 No. 12021

https://jurnalannur.ac.id/index.php/jalsah

al-hafizh al-'Iraqi dan Ibnu Hajar al-'Asqalani memberikan sanggahan khusus terhadap tuduhan palsu Ibn al-Jauzi akan kesahihan beberapa riwayat Imam Ahmad. sedangkan Jalaluddîn as-Suyuthi menulis al-Qaul al-Hasan fì al-żabbi an as-Sunan yang secara umum membantah segenap tuduhan palsu Ibn al-Jauzi terhadap riwayat Imam Bukhari, Muslim, Ahmad, Dâwud, Turmuzi, Nasầi, Ibnu Majah, Mustadrak al-Hakim, dan beberapa hadis lagi di berbagai literatur yang lain. Ringkasnya, sebagaimana yang telah disimpulkan oleh as-Syaikh Muhammad Mahfûzh bin Abdullah at-Turmuzi, mayoritas hadis yang diklaim palsu oleh Ibn al-Jauzi dalam beberapa karya kritisnya, semisal alMaud ü'ät dan al-'Ilal al-Mutanähiyah, adalah hadis shahîh, hasan atau juga daîf. kesimpulan ini diperkuat dengan adanya pernyataan Ibn as-Shalah bahwa Ibn al-Jauzi memang banyak memfonis palsu terhadap hadis daif tanpa ada dasar kepalsuan.

Di dalam kitab Ibya Ulüm ad-Din pada pembahasan halal-haram, al-Ghazali menyebutkan 105 buah hadis (termasuk matn hadis yang disebutkan berulang-ulang). Dari 105 buah hadis tersebut dibedakan antara lain yang berkualitas sahih: 48 buah hadis, berkualitas hasan 7 buah hadis, berkualitas daif 23 buah hadis, berkualitas mand $\bar{u}^{\prime} 8$ buah hadis dan redaksi matan hadis yang diulang-ulang 19 buah hadis. Berikut adalah beberapa contoh hadis yang dipergunakan oleh al-Ghazali dalam menguraikan pembahasan halalharam dalam kitabnya, Ibya Ulüm ad-Din. Contoh hadis yang berkualitas sahih: "Rasulullah saw berkata: "balal itu jelas dan haram pun jelas, diantara keduanya terdapat bal-bal yang syubhat (samar), yang kebanyakan manusia tidak mengetahuinya. Barangsiapa menjaga diri dari hal syubhat, maka ia telah membersibkan kehormatan dan agamanya. Dan barangsiapa terjerumus ke dalam hal syubhat, maka ia jatub dalam keharaman, seperti halnya seorang penggembala di sekitar tanah larangan, maka sangat dimungkinkan ia akan terjatub ke dalamnya". Contoh hadis yang berkualitas hasan: "Setiap daging yang tumbuh dari barang yang haram, maka neraka lebih utama baginya".

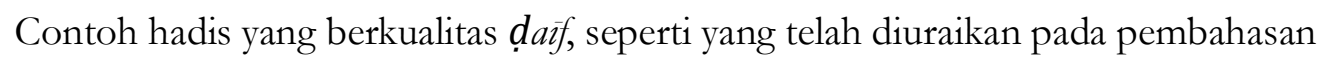
sebelumya bahwa jenis hadis daif itu sangat beragam, sesuai dengan sebab-sebab ke-daifannya. Beberapa contoh hadis daif di bawah ini terbatas pada jenis hadis daif yang terdapat pada pembahasan halal-haram dari kitab Ihya Ulüm ad-Din (Mahmud at-Tahhan, 1995:21):

- Hadis Mursal :

\footnotetext{
روت عائشة رضي الله عنها : ان رجلا اتى النبي صلى الله عليه وسلم بارنب فقال رميتي عرفت فيها

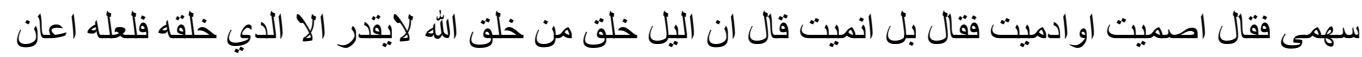
على قتلكه شيئ. "Aisyah ra. meriwayatkan bahwa ada seorang laki-laki membawa seekor Kelinci kepada Nabi saw. lalu ia berkata: "ini hasil panahanku, aku tahu anak panahku mengenainya". Kemudian Rasulullab bersabda: "binatang itu mati seketika atau setelah pergi?". Laki-laki itu menjawab: "aku mendapatinya mati setelah pergi". Rasulullah bersabda: "sesunggubnya malam adalah salah satu makbluk. Allah, tidak ada yang dapat ( melampaui) qadar-Nya kecuali sesuatu yang Dia ciptakan. Mungkin saja ada unsur lain yang menyebabkan kematiannya'.
} 
JALSAH: The Journal of al-Quran and as-Sunnah Studies

Faculty of Ushuludin IIQ An-Nur Yogyakarta

Vol. 1 No. 12021

https://jurnalannur.ac.id/index.php/jalsah

- Hadis Garib

$$
\text { ماروي عن النبي صلى الله عليه وسلم : انه سئل ان يكحل المسجد فقال لا, عريش كعريش موسى. }
$$

"Sesuatu yang telah diriwayatkm dari Nabi saw bahwasannya Nabi saw pemah ditanya tentang masjid yang dicat kehijau-hijauan, Kemudian beliau bersabda: "tidak, rumah seperti rumah Musa". (Diriwayatkan oleh ad-Daraqutni dari Abi adDarda')

- Hadis Mudtarib

$$
\begin{aligned}
& \text { بماروي ان رافع بن خديج رحمه مات وخلف ناضحا وعبدا حجاما فسئل رسول الله صلى الله عليه وسلم } \\
& \text { عن دلك فنهُى عن كسب الحجام فرجع مرات فمنع منه فقيل ان له ايتاما فقال اعلفوه الناضح. }
\end{aligned}
$$

"Telah diriwayatkan bahwasannya Rafi" Ibn Kbudaij Rabimabullah telah meninggal, ia meninggalkan seekor unta pembawa air siraman dan seorang hamba tukang bekam, lalu rasulullah saw ditanya tentang hal itu, maka beliau melarang mengambil hasil dari usaba bekam, lalu bal itu ditanyakan kembali bingga beberapa kali, rasulullah pun tetap melarangnya. Kemudian setelah rasulullah diberitabu babwa tukang bekam tersebut mempunyai beberapa anak yatim, maka rasulullah bersabda: "berikanlah makanan (upabnya) kepada unta pembawa air siraman". (Diriwayatkan oleh Abmad dan at-Tabrani dari Tbayah Ibn Rafi' ibn Khudaij).

- Hadis Munkar.

$$
\text { وقال صلعم : البدة عشرة اجز اء تسعة منه قى طلب الحلال. }
$$

Rasulullah saw berkata: "Ibadah itu terbagi menjadi sepulub bagian, sanbilan diantaranya adalah mencari barang halal". (Hadis yang diriwayatkkan oleh perawi da'if yang berbeda dengan perawi lain yang isiqah)

- Hadis Mu 'dal

$$
\text { قاب حماد لاانه قال عليه سلام : ان العالم ادا اراد بعلمه وجه الله هابه كل شيئ وان ارد ان يكنز به الكنوز }
$$

"Hammad berkata: "sesunggubnya orang 'alim itu, apabila dengan ilmunya ia menghendaki ridha Allah, maka ia akan ditakuti oleh segala sesuatu, dan jika dengan ilmunya ia bermaksud untuk menumpuk numpuk kekayaan (harta). maka ia takut terbadap sesuatu”. (Hadis yang dari segi sanadnya gugur dua atau lebih perawinya secara berturut turut)

- Hadis yang berkualitas maudhu'

$$
\text { وروب : ان سعد سأل رسول الله صلى الله عليه وسلم ان يسال الله تعالى ان يجعله مجاب الدعوة فقال له }
$$

'Telah diriwayatkan bahwasanya Sa'ad memohon kepada Rasulullah saw untuk memohonkan kepada Allab Ta'ala agar dikabulkan doa'anya. Lalu Rasulullah menjawab; perbaikilah makananmu, tentu doa'mu akan dikabulkan". (diriwayatkan oleh at-Tabrani dalam al-Ausat dari ibn' Abbas) 
JALSAH: The Journal of al-Quran and as-Sunnah Studies

Faculty of Ushuludin IIQ An-Nur Yogyakarta

Vol. 1 No. 12021

https://jurnalannur.ac.id/index.php/jalsah

\section{Kesimpulan}

Hadis dalam konsepsi pemikiran al-Ghazali merupakan sumber agama islam kedua setelah al-Qur'an. Menurutnya hadis merupakan wahyu yang tidak dibacakan secara langsung. Namun demikian tidak semua hahis dijadikan bujjah, melainkan harus diuji terlebih dahulu validitas dan otentisitasnya. Oleh karena itu, al-Ghazali mengklasifikasikan hadis menjadi tiga kategori, pertama hadis harus diterima kebenarannya. Kedua, hadis yang harus di tolak atau didustakan kebenarannya dan ketiga hadis yang harus diperlakukan netral atau ditangguhkan terlebih dahulu.

Lebih lanjut al-Ghazali mensyaratkan seorang perawi hadis yang dapat di terima periwatannya adalah: ia harus seorang mukalaf, muslim, adil, dan ḍābit (kuat hafalannya). Khusus untuk syarat mukalaf dan muslim, keduanya tidak disyaratkan oleh para ahli hadis lainnya. Dengan demikian al-Ghazali secara teoritis bersikap sangat ketat dalam hal penerimaan hadis.

\section{DAFTAR PUSTAKA}

Khoirun Nisa. (2016). Al-Ghazali: Ibya' Ulum Al-Din Dan Pembacanya. Jurnal Ummul Qura. Vol. 8 No.2.

Al-Ghazali. (1982). Mubtasar Ibya 'Ulüm ad-Din. Terjemahan Mokhtar Rosyidi. Yogyakarta: U.P Indonesia.

Amien, Miska M. (2007). Kerangka Epistemologi Al-Ghazali. Jurnal Filsafat 1, No. 1 1119. Https://Doi.Org/10.22146/Jf.31479.

Asari, Hasan. (2009). Petualangan Intelektual Al-Ghazali Dan Sardar Dalam Mencari Kebenaran. Islamica: Jurnal Studi Keislaman 4, No. 1: 108-19.

Https://Doi.Org/10.15642/Islamica.2009.4.1.108-119.

Al-Tahhan, Mahmud. (1995) Metode Takhrij dan Penelitian Sanad Hadis. Surabaya: PT. Bina Ilmu

Hanan, Zaini Abdul. (2019). Menakar Eksistensi Dan Pemikiran Al Ghazali Sebagai Figur Intlektual Islam. Jurnal Elkatarie : Jurnal Ilmu Pendidikan Dan Sosial 1, No. 02: 104 16. Https://Doi.Org/10.1234/Elkatarie.V1i02.3623.

Imam Al-Ghazali, Juhaya S.Praja. (1996). Hadis Dalam Khazanah Intelektual Muslim: Al-Ghazali Dan Ibnu Taimiyah”, Dalam Yunahar Ilyas Dan M. Mas'udi (Ed.), Pengembangan Pemikiran Terbadap Hadis. Yogyakarta: LPPI.

Irham, Masturi. (2015) Sejarah Dan Perkembangan Kritik Matn Hadis.” Mutawatir 1, No. 1: 96-112. 
JALSAH: The Journal of al-Quran and as-Sunnah Studies

Faculty of Ushuludin IIQ An-Nur Yogyakarta

Vol. 1 No. 12021

https://jurnalannur.ac.id/index.php/jalsah

Jamhari. (2015). Al-Ghazali Dan Oposisinya Terhadap Filsafat. Jurnal Ilmu Agama: Mengkaji Doktrin, Pemikiran, Dan Fenomena Agama 16, No. 1:108-19.

M. Amin Abdullah. (1996). Studi Agama: Normativitas Atai Historitas. Yogyakarta: Pustaka Pelajar.

Mansur Thoha Abdullah. (2003). Kritik Metodologi Hadis Tinjauan Atas Kontroversi Penikiran Al-Ghazali. Yogyakarta: Pustaka Rihlah.

Masturi Irham. (2015). Sejarah Dan Perkembangan Kritik Matn Hadis," Mutawatir1, No. 1

Mas'udi. (2013). Menyingkap Hubungan Agama Dan Filsafat: Merenda Kesesatan Filsafat Al-Ghazali, Merespons Keterhubungan Filsafat Dan Agama Ibnu Rusyd. Jurnal Penelitian 7, No. 2. Https://Doi.Org/10.21043/Jupe.V7i2.816.

Maulana, Luthfi. (2016). Periodesasi Perkembangan Studi Hadits (Dari Tradisi Lisan/Tulisan Hingga Berbasis Digital)." Esensia: Jurnal Ilmu-Ilmu Ushuluddin 17, No. 1 : 111-23. Https://Doi.Org/10.14421/Esensia.V17i1.1282.

Muhtador, Moh. (2019). Dinamika Memahami Hadis Nabi: Tinjauan Historis Dan Metodologis. Riwayah: Jurnal Studi Hadis 3, No. 2: 185-96.

Https://Doi.Org/10.21043/Riwayah.V3i2.3704.

Nasution, Syamruddin. (2015) Kajian Naskah: Kitab Sairu Al-Salikin Li Babi Ihya 'Ulumuddin Karya Syekh Ali Ibn Abdurrahman Al-Kalantani." Sosial Budaya 11, No. 1: 70-90. Https://Doi.Org/10.24014/Sb.V11i1.827.

Salihima, Syamsuez. (2010). Historiografi Hadis Hasan Dan Dhaif." Jurnal Adabiyah 10, No. 2: 212-22.

Sidik, Nur. (2020). Open Journal Systems.

Https://Doi.Org/10.21043/Esoterik.V4i1.4499.

Suryadi. (2015). Rekonstruksi Kritik Sanad Dan Matan Dalam Studi Hadis.” Esensia: Jurnal Ilmu-Ilmu Ushuluddin 16, No. 2: 177-86.

Https://Doi.Org/10.14421/Esensia.V16i2.996.

Suryadilaga, Muhammad Alfatih. (2014). Kajian Hadis Di Era Global.” Esensia: Jurnal Ilmu-Imu Usbuluddin 15, No. 2: 199-212.

Https://Doi.Org/10.14421/Esensia.V15i2.773.

. (2017). Kontekstualisasi Hadits Dalam Kehidupan Berbangsa Dan Berbudaya.

Kalam 11, No. 1: 215-34. Https://Doi.Org/10.24042/Klm.V11i1.904. 
JALSAH: The Journal of al-Quran and as-Sunnah Studies

Faculty of Ushuludin IIQ An-Nur Yogyakarta

Vol. 1 No. 12021

https://jurnalannur.ac.id/index.php/jalsah

Yasykur, Moch. (2017). Konsep Ilmu Keislaman Al-Ghazali Dalam Perkembangan

Pendidikan Islam Masa Kini." Edukasi Islami: Jurnal Pendidikan Islam 3, No. 06.

Https://Doaj.Org.

Zaini Abdul Hanan. (2019). Menakar Eksistensi Dan Pemikiran Al Ghazali Sebagai Figur Intlektual Islam. Jurnal Elkatarie: Jurnal Ilmu Pendidikan Dan Sosial 1, No. 02: 104-16, Https://Doi.Org/10.1234/Elkatarie.V1i02.3623. 